\title{
Principal component analysis of body measurements and body indices and their correlation with body weight in Katjang does of Indonesia
}

\begin{abstract}
The present study was aimed to investigate the body measurements and body indices of Kacang do at Bone Bolango Regency of Indonesia. A total of 85 does (3years age) were recorded and analyzed by principal component analysis (PCA) to explain the body measurements and body indices. Eleven body measurements of face length (FL), face width (FW), face height (FH), ear length (EL), ear width (EW), body length (BL), withers height $(\mathrm{WH})$, chest width $(\mathrm{CW})$, chest depth $(\mathrm{CD})$, chest girth $(\mathrm{CG})$, cannon bone circumference $(\mathrm{CC})$ and eleven body indices of cephalic index $(\mathrm{CpI})$ length index (LI), depth index (DI), body index (BI), conformation index (CI), proportionality (Pr), relative depth of thorax (RDT), dactyl thorax index (DTI), thoracic development (TD), area index (AI), and relative cannon thickness index (RCTI) were calculated in this study. Four components of body measurements (FH, BL, CD, CG) and three components of body indices (CI, TD, RCTI) were identified as the first component (PC1) for Katjang does. The result suggests that the highly $\mathrm{R} 2$ value $(0.61<\mathrm{R} 2<0.80)$ were obtained in linear regression of BW with CG $(0.69)$ or PC1 $(0.71)$ as predictors. The R2 value in linear regression of BW using body indices through PC1 and PC2 as predictors was showed moderate category $(\mathrm{R} 2=0.72)$.
\end{abstract}

Keywords: body measurements, body indices, body weight, katjang does, PCA
Volume 8 Issue 3 - 2019

\author{
Widya Pintaka Bayu Putra,' Fahrul Illham² \\ 'Department of Animal Breeding and Genetics, Faculty of Animal \\ Sciences, Gadjah Mada University, Indonesia \\ ${ }^{2}$ Departement of Animal Science, Faculty of Agriculture, \\ Gorontalo State University, Indonesia
}

Correspondence: Widya Pintaka Bayu Putra, M.Sc., Department of Animal Breeding and Genetics, Faculy of Animal Sciences, 5528I Bulaksumur, Sleman, Indonesia, Tel 0878-3819. 7243, Email widya.putra.lipi@gmail.com

Received: October 19, 2018| Published: May 17, 2019

\section{Introduction}

Goats are important livestock in Indonesia because of their adaptation to harsh climates conditions, disease tolerance capacity and they can provide a full range of products for humans especially of meat production Total of goat population numbers in Indonesia at 2015 about $18,880,000$ heads with total of meat production at 2015 about $65,900 \mathrm{~kg}$ mean while, total of goat for slaughters at 2015 about 1,819,812 heads. ${ }^{1}$ Bone Bolango Regency is located at Gorontalo Province (Sulawesi Island) that one of goat breeding tract in Gorontalo province. Total of goat population in Bone Bolango Regency at 2011 reached 5,872 heads and about $7.0 \%$ from total population at Gorontalo province. ${ }^{1}$ The Katjang goat is a largest indigenous goat in Indonesia and used for meat production. Genetic improvement of indigenous livestock species is of importance because of their adaptation to harsh climatic condition and their disease tolerance capacity. The meat productions of Katjang bucks i.e. slaughters weight, carcass weight, carcass percentage and non carcass percentage were $25.56 \mathrm{~kg}, 11.94 \mathrm{~kg}, 46.80 \%$ and $53.20 \%$ respectively under feed ration containing soybean meal. ${ }^{2}$ The litter size of Katjang does such were $2.95 \mathrm{kid} /$ doe/year with kidding interval in the $1^{\text {st }}, 2^{\text {nd }}$, $3^{\text {rd }}, 4^{\text {th }}, 5^{\text {th }}$ and $6^{\text {th }}$ parities were $271,262,243,217,223$ and 239 days respectively. ${ }^{3}$ Growth and development is important for production of meat animals. Body measurements are important parameters to describe growth. In addition to estimate body measurements and body indices can be described completely an individual or a population. Therefore, linear body measurements can be used as selection criteria for improvement of meat production in goat. Body conformation by recording of minimum body measurements which reduce the cost, labour and time is the need of the day. Body measurements in addition to weight measurements describes more completely an individual or population than do the conventional methods of weighing and grading. EAAP and FAO have used wither height for example as a prime indicator of grade. ${ }^{4}$ Desirable body conformation, from the meat production viewpoint, is such a complex character that little progress has been made in reducing it to a single corporal measurement which can be taken on the live animal. Body indices from different body measurements, an objective assessment of body conformation from the standpoint of type may be relatively easier. ${ }^{5}$ Combination of different linear measurements in the body indices may be more useful to describe the type and function of animal. A more reliable assessment of morpho metric relationship among livestock breed has been obtained using multivariate statistical tools such as principal component analysis. ${ }^{6}$ Principal component analysis (PCA) is an interdependence technique whose primary purpose is to define the underlying structure among the variables under study. Though the number of components generated in PCA equals the number of variables in the study, first few components accounts for the highest proportion of the total variance. The PCA has been used as a tool in the assessment of the body conformation which can be conducted to understand of the complex growth process in the body dimensions of an animal during growth period. Results of principal component analysis not only impact the management of animals but also help in conservation and selection of multiple traits by breeders. ${ }^{7}$ The PCA of body measurements in livestock were also used to explain body conformation in several livestock such as goat, ${ }^{8-19}$ sheep,,${ }^{6,12,20-25}$ cattle, ${ }^{26-31}$ buffalo, ${ }^{32}$ horse ${ }^{33}$ chicken $^{34}$ and rabbit. ${ }^{13,14}$ Despite, previous study reported that the PCA of body measurements were also used to predict body weight in goat,,$^{8-11}$ sheep $^{12}$ and rabbit. ${ }^{13,14}$ This study was aimed at providing objective description of body measurements and body indices of Katjang does from Bone Bolango regency using principal component analysis (PCA). It also tested the hypothesis 
that the relationships involving body weight and morphological traits may be different when body measurements derived from the PCA were used instead of the inter-correlated original morphological variables. The information obtained would be helpful to researchers and livestock producers with policies to assist conservation and sustainable utilization of the Katjang goat genetic resources by the proper use of morphological traits.

\section{Materials and methods}

\section{Research site and animals}

This research was conducted at Bone Bolango Regency, Gorontalo Province, Indonesia. This area is situated at latitude $00018^{\prime} 25^{\prime \prime}$ to $00048^{\prime} 21 " \mathrm{~N}$ and longitude 123003 ' 41 " to $123033^{\prime} 06 " \mathrm{E}$ about $0-1500 \mathrm{~m}$ above the sea level. The humidity $71.8-88.9 \%$ with temperature $24.4-28.00 \mathrm{C}$ and rainfall occurring $38-378 \mathrm{~mm}$. Total of 85 animals (3pairs of permanent incisors) were measured for the principal component analysis (PCA) Body measurements and body weight. All animals were measured using measuring tape (butterfly, China) and measuring stick and taken based on previous studies. ${ }^{6,18,19,25,31}$ Eleven body measurements were conducted on each goats such as face length (FL: measured from between the horn site/ poll to the lower lip), face width (FW: measured as the widest point of the head), face height (FH: measured from the poll to the jaw), ear length (EL: the distance from the base to the tip of the ear along the dorsal surface), ear width (EW: maximum distance at the middle of the ear), body length (BL: distance from the point of the shoulder to the pin bone), withers height (WH: vertical distance from ground to the point of withers measured vertically from the ridge between the shoulder bones to the fore hoof), chest width (CW: measured as a distance from left to right upper arm), chest depth (CD: the distance from the backbone at the shoulder to the brisket between the front legs), chest girth (CG: perimeter of the chest just behind the front legs and withers) and cannon bone circumference (CC: the smallest circumference of the cannon bone of foreleg). All body measurements were taken by technicians accredited by association. The scheme of body measurements in the Katjang doe was presented in Figure 1. Meanwhile, body weight of each animal was measured using hanging weight scale (CAMRY, China).

\section{Body indices}

Calculation of body indices were obtained according to previous studies ${ }^{10,21,35}$ as follow:

Cephalic index $(\mathrm{CpI})=(\mathrm{FW} \times 100) / \mathrm{FL}$

Length index $(\mathrm{LI})=\mathrm{BL} / \mathrm{WH}$

Depth index $(\mathrm{DI})=\mathrm{CD} / \mathrm{WH}$

Body index $(\mathrm{BI})=(\mathrm{BL} / \mathrm{CG}) \times 100$

Conformation index $(\mathrm{CI})=\mathrm{CG} 2 / \mathrm{WH}$

Proportionality $(\mathrm{Pr})=(\mathrm{WH} / \mathrm{BL}) \times 100$

Relative depth of thorax $(\mathrm{RDT})=(\mathrm{CD} / \mathrm{WH}) \times 100$

Dactyl thorax index $(\mathrm{DTI})=(\mathrm{CC} / \mathrm{CG}) \times 100$

Thoracic development $(\mathrm{TD})=\mathrm{CG} / \mathrm{WH}$

Area index $(\mathrm{AI})=\mathrm{WH} \times \mathrm{BL}$

Relative cannon thickness index $(\mathrm{RCTI})=(\mathrm{CC} / \mathrm{WH}) \times 100$

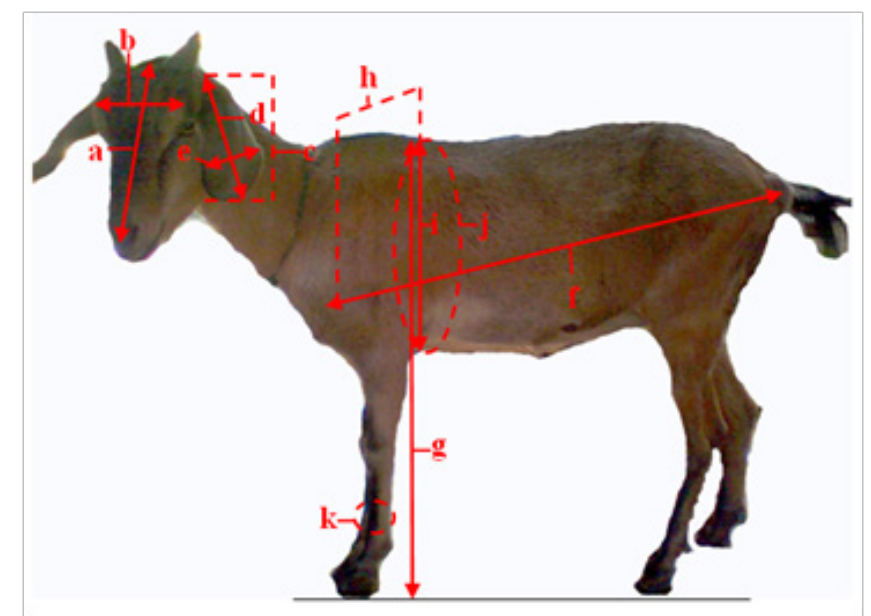

Figure I Scheme of body measurements in the Katjang doe consisted of face length (a), face width (b), face height (c), ear length (d), ear width (e), body length (f), withers height $(g)$, chest width (h), chest depth (i), chest girth (j) and cannon bone circumference $(\mathrm{k})$.

\section{Statistical analysis}

Data of body measurements and body indices were analyzed using Microsoft Office Excel 2007 computer program to describe mean, standard deviation (SD), coefficient of variation (CV) and minimum/maximum values. The phenotypic correlation $(\mathrm{r})$ and the variance-covariance values were also determined. From the variancecovariance matrix, data for the PCA of body measurements and body indices were generated. The PCA equation as follows: ${ }^{16}$

$$
P C_{p}=a_{1 p} X_{1}+a_{2 p} X_{2}+\ldots \ldots \ldots \ldots \ldots+a_{n p} X_{n}
$$

Where, $\mathrm{PC}_{\mathrm{p}}$ is the pth principal component; anp is the nth vector Eigen of the pth principal component and $\mathrm{X}_{\mathrm{n}}$ is the $\mathrm{nth}$ observed variables. Kaiser-Meyer-Olkin (KMO) test of sampling adequacy and Bartlett's test of sphericity were computed to establish the validity of the data set KMO's measure determines whether the common factor model is appropriate. The KMO should be greater than 0.50 for a satisfactory factor analysis to proceed. Rotation of principal components was through the transformation of the components to approximate a simple structure. The raw varimax criterion of the orthogonal rotation method was employed for the rotation of the factor matrix (the aim of the varimax rotation is to maximize the sum of variances of a quadratic weight). Cumulative proportion of variance criterion was finally employed to determine the number of components to extract. Simple and multiple linear regressions were performed in this study for identified the accuracy in each components when used as BW predictors. The linear regression equation as follows: ${ }^{8}$

$$
\begin{aligned}
& B W=\beta_{0}+\beta_{1} X_{1}+\beta_{2} X_{2}+\ldots \ldots \ldots+\beta_{n} X_{n} \\
& B W=\beta_{0}+\beta_{1} P C_{1}+\beta_{2} P C_{2}+\ldots \ldots \ldots+\beta_{n} P C_{n}
\end{aligned}
$$

Where, BW is the body weigh; $\beta_{0}$ is the intercept; $\beta_{\mathrm{n}}$ is the regression coefficient, $X_{n}$ is the $n$th observed variables and $P_{n}$ is the nth observed principal component. The tatistic analysis for principal component and regression analysis were performed using SPSS 16.0 computer program. 


\section{Results and discussion}

\section{Body measurements and body weight}

The descriptive statistics for all the body measurements was presented in Table 1 and the body measurements of several goat and sheep in the world was presented in Table 2. The moderate of CV value $(0.10<\mathrm{CV}<0.20)$ were obtained on measurements of $\mathrm{FL}, \mathrm{FW}$, $\mathrm{EL}, \mathrm{CW}$ and $\mathrm{BW}$. Therefore, the low of $\mathrm{CV}$ value $(\mathrm{CV}<0.10)$ were obtained on the other measurements. Body a measurement of WH and CG in Katjang does in the present study were higher than Malaysian Katjang (MK) does. However, BL in this study was lower than MK does (Table 2). Moreover, most of the body measurements of Katjang does in this study were highest than Black Bengal and West African Dwarf (WAD) does. According to the Table 2, body measurements of Katjang does in this study were lowest than several sheep breeds. The variation among breeds can be caused by the difference of genetic, nutrition, management system and climate.

\section{Body indices}

The descriptive statistics for all body indices was presented in Table 1. Moderate CV value were showed in body indices of CpI, $\mathrm{CI}, \mathrm{AI}$ and FoL. Therefore, the lowly CV values were obtained on the other body indices. The body indices of Cuban Creole does were BI (85.29 \pm 5.57$), \mathrm{CpI}(63.65 \pm 3.49), \operatorname{Pr}(93.19 \pm 3.77), \mathrm{RDT}(47.66 \pm 1.42)$, DTI $(9.58 \pm 0.50)$ and CI $(97.01 \pm 3.96) .{ }^{35}$ In addition, the body indices of Assam Hill does according to Khargharia et al. (2015) were LI (1.14 \pm 0.02$)$, DI $(0.51 \pm 0.01)$, BI $(86.87 \pm 0.85), \operatorname{Pr}(88.52 \pm 1.21)$, RDT $(50.88 \pm 0.71)$ DTI $(9.82 \pm 0.38)$, TD $(1.32 \pm 0.02)$, AI $(3355.13 \pm 48.84)$ and RCTI $(12.95 \pm 0.14) .{ }^{10}$ Meanwhile, the body indices of LI and DI were 1.01 and 0.53 respectively for WAD sheep and about 0.93 and 0.52 respectively for Yankasa sheep. ${ }^{7}$ Body indices of BI, DTI and $\mathrm{AI}$ in the Katjang does in this study were higher than Assam Hill does. Thus, body indices of BI, Pr, DTI and CpI of Katjang does were higher than Cuban Creole does. According to BI value, the goat can be described three category such as brevigline $(\mathrm{BI}<0.85)$, medigline $(0.86<\mathrm{BI}<0.88)$ and longiland $(\mathrm{BI}>0.88)$. Moreover, according to DTI value, the goat can be described as four category such as light animals $(\mathrm{DTI}<10.5)$, intermediary $(10.6<\mathrm{DTI}<10.8)$, light meat animals $(10.9<\mathrm{DTI}<11.0)$ and heavy meat animals $(11.1<\mathrm{DTI}<11.5)$. Goats with TD more than 1.2 were included of good performance. ${ }^{10,35}$ The Katjang does in this study can be described as light meat animals $(\mathrm{DTI}=10.24)$ and medigline animals $(\mathrm{BI}=86.95)$ with good of thoracic development $(\mathrm{TD}=1.24)$.

\section{Phenotypic correlations}

The phenotypic correlations (r) among body measurements and body indices were presented in Table 3 and Table 4 respectively. The highest $r$ values were reached between CG and BW (0.83) and included of the very high category $(0.80<\mathrm{r}<1.00)$. Meanwhile, the highly $\mathrm{r}$ value $(0.61<\mathrm{r}<0.80)$ among different body measurements were showed between FL-EW (0.62), EL-EW (0.63) and CC-CG (0.61). The highly $\mathrm{r}$ value were showed between BW and somebody indices of CI (0.69) and AI (0.64). Meanwhile, the highly $r$ value among different body indices were showed between LI-TD (0.68), TD-DI (0.61), TD-Pr (0.67), TD-RDT (0.61) and RCTI (0.61). The strongly $\mathrm{r}$ value $(0.81<\mathrm{r}<1.00)$ were showed between LI-Pr $(0.98)$, RDT-DI (0.99) and TD-CI (0.88). Previous studies reported that the highly $\mathrm{r}$ values between $\mathrm{CG}$ and $\mathrm{BW}$ were reported in some goat breeds of Assam Hill (0.79), ${ }^{8}$ Pakistan commercial goat $(0.76),{ }^{9}$
Atlas (0.91), ${ }^{10}$ Barcha (0.77), ${ }^{15}$ Black Bengal (0.85), ${ }^{19} \mathrm{MK}(0.88),{ }^{36}$ Red Sokoto (0.94), ${ }^{38}$ WAD $(0.91),{ }^{38}$ and 0.82 for Kilkecisi. ${ }^{38}$ Despite, highly $\mathrm{r}$ values between $\mathrm{CG}$ and BW were reported in some sheep breeds such as Zulu (0.88), ${ }^{7}$ Balami $(0.80),{ }^{22}$ WAD $(0.81),{ }^{24}$ Yankasa $(0.85)^{24}$ and 0.70 for Djallonke. ${ }^{25}$ The $r$ values of EL-EW, CD-EL and CD-EW in Kilkecisi does were $0.77 ; 0.32$ and 0.25 respectively ${ }^{37}$ and higher than Katjang does in the present study. Thus, the $\mathrm{r}$ value between DI and LI in WAD and Yankasa sheep's was 0.95 and 0.76 respectively7 and showed higher than Katjang does in the present study (0.57). Body measurement of CG in the Katjang does in this study can be influenced of BW because of highly correlation $(\mathrm{r}=0.83)$.

\section{Principal component analysis}

The communalities value, total variance explained by different components and rotated component matrix of different body measurements and body indices of Katjang does in this study were presented in Table 5, Table 6 and Table 7 respectively. The measure of sampling adequacy, Kaisee-Meyor-Olicn (KMO) of body measurements and body indices were 0.80 and 0.58 respectively. The overall significance of the correlations tested with Bertlett's test of Sphericity for the body measurements (Chi-squared was 362.32; $\mathrm{p}<0.01$ ) and body indices (chi-squared was 2,113.00; $\mathrm{p}<0.01$ ) were significant and provided enough support for the validity of the factor analysis of data. The communality values ranged from 0.44 (WH) to $0.81(\mathrm{CG})$ for body measurements and $0.40(\mathrm{CI})$ to $0.99(\mathrm{BI})$ for body indices (Table 5) The screen plot of component number with eigen values for body measurements and body indices of Katjang does is given in Figure 2. There were three components extracted from different body measurements with Eigen values greater than 1.00 and accounted for $64.89 \%$ of total variance (Table 6 ).

Therefore, four components extracted from different body indices and accounted for $86.84 \%$ of total variance. The first (PC1), second (PC2) and third (PC3) components of body measurements were explained the does body about $41.31 \%, 13.71 \%$ and $9.87 \%$ of total variance respectively. Thus, $\mathrm{PC}_{1}, \mathrm{PC}_{2}, \mathrm{PC}_{3}$; and $\mathrm{PC}_{4}$ of body indices were explained does body about $41.50 \%, 16.36 \%, 15.71 \%$ and $13.28 \%$ of total variance respectively. According to Table 7, the negative assigned weight of different body measurements were found on $\mathrm{PC}_{1}$ $(\mathrm{FW})$ and $\mathrm{PC}_{2}(\mathrm{CW}$ and $\mathrm{CD})$. Thus, the negative assigned weight of different body indices were found on $\mathrm{PC}_{1}\left(\mathrm{CI}, \mathrm{BI}, \mathrm{Pr}\right.$ and DTI), $\mathrm{PC}_{2}$ (CI, Pr and DTI), $\mathrm{PC}_{3}$ (BI, CI, Pr, DTI and $\mathrm{AI}$ ) and $\mathrm{PC}_{4}$ (LI, DI, CI, RDT, TD and AI). Component plot of body measurements according to rotated component matrix is given in Figure 3. Three principal components of different body measurements was obtained in Katjang does and similar to Yankasa sheep6, Pakistan commercial goats, ${ }^{9}$ Red Sokoto goats, ${ }^{16}$ Nigerian indigenous goat, ${ }^{18}$ Bargamesca ewes ${ }^{20}$ and Balami sheep. ${ }^{22}$ The communality value of CG in the present study was highest (0.81) than other measurements. Previous studies reported that the communality value of CG was highest than other body measurements in WAD does ${ }^{8}$ Nigerian indigenous goat ${ }^{18}$ and Zulu sheep..$^{24}$ All body measurements and body indices in $\mathrm{PC}_{1}$ group were determined as the important measurements for goat selection.

\section{Regression linear}

Linear regression model of BW based on the original body measurements and body indices and their component score were presented in Table 8 and Table 9 respectively. According to Table 8 , the highly coefficient of determination $\left(\mathrm{R}^{2}\right)$ value $\left(0.61<\mathrm{R}^{2}<0.80\right)$ were found in linear regression using $\mathrm{CG}$ as the independent variable 
$\left(\mathrm{R}^{2}=0.69\right)$ and using $\mathrm{FH}, \mathrm{BL}, \mathrm{CG}$ and $\mathrm{CD}$ as the independent variables $\left(\mathrm{R}^{2}=0.71\right)$. Therefore, the $\mathrm{R}^{2}$ value of simple linear regression with one component of $\mathrm{PC}_{1}(0.63)$ was similar to $\mathrm{R} 2$ value of multiple linear regression with two components $\left(\mathrm{PC}_{1}, \mathrm{PC}_{2}\right)$ or three components $\left(\mathrm{PC}_{1}, \mathrm{PC}_{2}, \mathrm{PC}_{3}\right)$. According to Table 9, the highly $\mathrm{R}^{2}$ value was found in multiple linear regression with independent variables of CI, RCTI, TD and similar to the simple linear regression with variable of $\mathrm{CG}\left(\mathrm{R}^{2}=0.69\right)$. Thus, the $\mathrm{R}^{2}$ value of multiple linear regression with two components of $\mathrm{PC}_{1}$ and $\mathrm{PC}_{2}$ as independent variables was 0.72 and similar to $\mathrm{R}^{2}$ value of multiple linear regression with three components $\left(\mathrm{PC}_{1}, \mathrm{PC}_{2}, \mathrm{PC}_{3}\right)$ or four components $\left(\mathrm{PC}_{1}, \mathrm{PC}_{2}, \mathrm{PC}_{3}, \mathrm{PC}_{4}\right)$. Previous study showed that the $\mathrm{R}^{2}$ values in simple linear regression of BW based on CG measurement in some goat/sheep were 0.55 (adult Zulu sheep), ${ }^{8} 0.62$ (Assam Hill does) ${ }^{10}$ and 0.89 (Red Sokoto does). ${ }^{24}$ Therefore, the $\mathrm{R}^{2}$ value of simple linear regression with
PC1 as independent variable in those breeds were 0.69 (adult Zulu sheep), ${ }^{8} 0.64$ (Assam Hill does) ${ }^{10}$ and 0.63 for Red Sokoto does. ${ }^{24}$ The prediction of BW based on principal component (PC) was more accurate than original body measurements. ${ }^{24}$ However, the several study reported that prediction of BW based on PC were not accurate in Red Sokoto goat8, Pakistan commercial goat9 and Assam Hill does10. Prediction of BW in using original body measurements of $\mathrm{PC}_{1}$ in this study was more appropriate $\left(\mathrm{R}^{2}=0.71\right)$ than the use of three principle components of body measurements $\left(\mathrm{R}^{2}=0.69\right)$. Therefore, prediction of body weight based on four elements of body indices was more appropriate $\left(\mathrm{R}^{2}=0.72\right)$ than the use of original body indices of $\mathrm{PC}_{1}\left(\mathrm{R}^{2}=0.69\right)$. The $\mathrm{R}^{2}$ value in linear regression model 1 was highest than model 2, 3 (body measurements and body indices) and 4 (body indices) and suggested that all factors in $\mathrm{PC}_{1}$ were important to explain the body of does in this study.

Table I Descriptive statistic of body measurements and body indices of Katjang does of Indonesia.

\begin{tabular}{|c|c|c|c|c|c|}
\hline Parameter & Mean & SD & CV (\%) & Min. & Max. \\
\hline \multicolumn{6}{|l|}{ Body measurements $(\mathrm{cm})$} \\
\hline Face length & 14.12 & 1.45 & 10.29 & 10 & 19 \\
\hline Face width & 10.94 & 1.31 & 12.01 & 8.5 & 16 \\
\hline Face height & $|2.3|$ & 1.04 & 8.41 & 10.5 & 15 \\
\hline Ear length & 14.86 & 1.68 & 11.28 & 12 & 19 \\
\hline Ear width & 7.12 & 0.68 & 9.51 & 5.9 & 9 \\
\hline Body length & 60.26 & 4.27 & 7.08 & 49.6 & 69.7 \\
\hline Withers height & 56.26 & 3.84 & 6.83 & 49 & 68 \\
\hline Chest width & 15.33 & 1.93 & $|2.6|$ & 10 & 20 \\
\hline Chest depth & 25.97 & 1.98 & 7.64 & 18.5 & 30 \\
\hline Chest girth & 69.42 & 4.64 & 6.69 & 58 & 81 \\
\hline Cannon bone circumference & 7.1 & 0.64 & 8.99 & 6 & 9 \\
\hline Body weight (kg) & 27.11 & 4.93 & 18.18 & 17 & 42 \\
\hline \multicolumn{6}{|l|}{ Body indices } \\
\hline Cephalic index & 77.91 & 10.01 & 12.85 & 63.33 & 133.33 \\
\hline Length index & 1.07 & 0.09 & 8.28 & 0.75 & 1.34 \\
\hline Depth index & 0.46 & 0.04 & 8.79 & 0.31 & 0.56 \\
\hline Body index & 86.95 & 5.4 & 6.21 & 73.61 & 102.24 \\
\hline Conformation index & 86.06 & 10.25 & 11.92 & 63.47 & II 15.57 \\
\hline Proportionality & 93.71 & 8.15 & 8.7 & 74.37 & 133.33 \\
\hline Relative depth of thorax & 46.32 & 4.07 & 8.79 & 31.15 & 55.77 \\
\hline Dactyl thorax index & 10.24 & 0.73 & 7.14 & 8.57 & 11.94 \\
\hline Thoracic development & 1.24 & 0.09 & 6.97 & 0.99 & 1.5 \\
\hline Area index & 3394.46 & 379.2 & 11.17 & 2430.4 & 4596.8 \\
\hline Relative cannon thickness index & 12.64 & 1.08 & 8.56 & 10.34 & 15.84 \\
\hline
\end{tabular}

$\mathrm{N}$, number of observation; SD, standard deviation; CV, coefficient of variation; Min, minimum value; Max, maximum value 
Table 2 The Means of body measurements in several breeds of adult goat and sheep in the world.

\begin{tabular}{|c|c|c|c|c|c|c|c|c|c|c|c|c|c|}
\hline $\begin{array}{l}\text { Species / } \\
\text { Breeds }\end{array}$ & Sex & BW & FL & FW & EL & EW & BL & WH & CW & CD & CG & CC & Reference \\
\hline \multicolumn{14}{|l|}{ Goat } \\
\hline $\begin{array}{l}\text { Malaysian } \\
\text { Katjang }\end{array}$ & Female & 23.65 & 14.58 & 11.91 & 13.27 & - & 70.5 & 50.21 & - & - & 63.46 & - & (36) \\
\hline Cuban Creole & Female & - & |7.7| & II.24 & 12.68 & - & 65.54 & 60.97 & 16.36 & - & 76.87 & 7.36 & (35) \\
\hline Assam Hill & Female & 24.86 & - & - & - & - & 61.48 & 54.57 & - & 27.68 & 71.93 & 7.71 & $(10)$ \\
\hline $\begin{array}{l}\text { Andalusian } \\
\text { White }\end{array}$ & Female & - & 22.46 & 13.65 & - & - & 80.25 & 73.64 & - & 33.55 & 89.85 & 9.87 & (38) \\
\hline Florida & Female & - & 25.54 & 12.78 & - & - & 80.54 & 77.91 & - & 34.79 & 90.92 & 9.24 & (38) \\
\hline Granada & Female & - & 18.53 & 12.4 & - & - & 73.97 & 68.22 & - & 30.98 & 85.59 & 7.97 & (38) \\
\hline Malaga & Female & - & 17.94 & 12.84 & - & - & 71.64 & 69.44 & - & 30.97 & 87.52 & 8.72 & (38) \\
\hline $\begin{array}{l}\text { Andalusian } \\
\text { Black }\end{array}$ & Female & - & 22.39 & 13.67 & - & - & 81.25 & 76.98 & - & 35.01 & 96.24 & 9.96 & (38) \\
\hline $\begin{array}{l}\text { West African } \\
\text { Dwarf }\end{array}$ & Overall & 17.14 & - & 9.41 & - & - & 45.1 & 44.09 & 10.81 & 26.43 & 60.09 & - & $(16)$ \\
\hline Red Sokoto & Overall & 22.32 & - & 12.13 & - & - & 51.63 & 62.34 & 14.24 & 31.42 & 69.81 & - & $(16)$ \\
\hline Barcha & Female & 36.9 & 24 & - & 21 & 8.8 & 98.7 & 71.4 & - & - & 74.7 & - & (19) \\
\hline Atlas & Female & 38.3 & 24 & - & 20.5 & 8.54 & 99.5 & 71.6 & - & - & 75.6 & - & (19) \\
\hline Black Bengal & Female & 12.4 & 15.1 & 10.55 & 11.9 & - & 42.15 & 43.1 & - & - & 53.4 & - & (I5) \\
\hline Norduz & Female & - & 41.32 & - & - & - & 67.63 & 65.64 & 22.34 & 31.44 & 89.43 & - & (39) \\
\hline Honamli & Female & 63.5 & - & - & - & - & 88.3 & 83 & - & - & 91 & - & $(40)$ \\
\hline \multicolumn{14}{|l|}{ Sheep } \\
\hline Djallonke & Female & - & - & - & - & - & 54.87 & 57.06 & - & 25.66 & 65.19 & - & $(25)$ \\
\hline Yankasa & Overall & 41.6 & - & - & - & - & 70.9 & 76.16 & 15.08 & - & 86.63 & - & (7) \\
\hline Uda & Overall & - & 21.47 & - & - & - & 59.37 & 65.83 & 14.4 & - & 71.98 & - & $(2 I)$ \\
\hline Assaf & Female & 75.74 & 31.11 & 14.52 & 17.9 & 10.33 & - & - & 26.85 & - & - & - & (23) \\
\hline Balami & Overall & 53.01 & - & - & - & - & 96.06 & 83.96 & 27.85 & - & 95.05 & - & $(22)$ \\
\hline Zulu & Female & 33.39 & 18.84 & 10.86 & 9.51 & - & 63.82 & 63.18 & - & 32.7 & 79.26 & 9.3 & (24) \\
\hline Bergamasca & Female & - & - & - & - & - & 78.3 & 79.5 & 23.8 & - & 99 & - & (20) \\
\hline Dombos & Female & - & - & - & - & - & 61.89 & 63.14 & 22.1 & 30.47 & 93.65 & - & $(4 I)$ \\
\hline
\end{tabular}

FL, face length; FW, face width; EL, ear length; EW, ear width; $B L$, body length;WH, withers height; $C W$, chest width; $C D$, chest depth; $C G$, chest girth; $C C$, cannon bone circumference

Citation: Putra WPB, llham F. Principal component analysis of body measurements and body indices and their correlation with body weight in Katjang does of Indonesia.J Dairy Vet Anim Res. 2019;8(3): I24-I34. DOI: I0.15406/jdvar.2019.08.00254 
Table 3 Phenotypic correlation between body weight and body measurements in Katjang does of Indonesia.

\begin{tabular}{|c|c|c|c|c|c|c|c|c|c|c|c|c|}
\hline Variables* & BW & FL & FW & $\mathbf{F H}$ & EL & EW & BL & WH & CW & CD & CG & CC \\
\hline Body weight (BW) & I & 0.55 & 0.15 & 0.59 & 0.25 & 0.38 & 0.56 & 0.43 & 0.31 & 0.38 & 0.83 & 0.56 \\
\hline Face length (FL) & - & I & 0.39 & 0.42 & 0.43 & 0.62 & 0.45 & 0.42 & 0.24 & 0.25 & 0.58 & 0.59 \\
\hline Face width (FW) & - & - & I & $0.20^{\text {ns }}$ & $0.18^{\text {ns }}$ & 0.3 & $0.17^{\mathrm{ns}}$ & 0.27 & 0.24 & $0.07^{\mathrm{ns}}$ & 0.23 & 0.49 \\
\hline Face height $(\mathrm{FH})$ & - & - & - & I & 0.24 & 0.29 & 0.41 & 0.37 & 0.27 & 0.3 & 0.58 & 0.3 \\
\hline Ear length (EL) & - & - & - & - & I & 0.63 & 0.29 & 0.24 & $0.03^{\text {ns }}$ & $-0.02^{\mathrm{ns}}$ & 0.21 & 0.35 \\
\hline Ear width (EW) & - & - & - & - & - & 1 & 0.45 & 0.42 & 0.19 & $0.02^{\mathrm{ns}}$ & 0.44 & 0.45 \\
\hline Body length (BL) & - & - & - & - & - & - & I & 0.27 & 0.2 & 0.41 & 0.6 & 0.38 \\
\hline Withers height (WH) & - & - & - & - & - & - & - & I & 0.31 & 0.25 & 0.46 & 0.45 \\
\hline Chest width (CW) & - & - & - & - & - & - & - & - & I & 0.29 & 0.5 & 0.3 \\
\hline Chest depth (CD) & - & - & - & - & - & - & - & - & - & I & 0.48 & $0.17^{\mathrm{ns}}$ \\
\hline Chest girth (CG) & - & - & - & - & - & - & - & - & - & - & I & 0.61 \\
\hline Cannon bone circumference (CC) & - & - & - & - & - & - & - & - & - & - & - & I \\
\hline
\end{tabular}

$*(\mathrm{P}<0.05) ; \mathrm{ns}(\mathrm{P}>0.05)$

Table 4 Phenotypic correlation between body weight and body indices in Katjang does of Indonesia.

\begin{tabular}{|c|c|c|c|c|c|c|c|c|c|c|c|c|}
\hline Body indices* & BW & Cpl & LI & DI & BI & Cl & Pr & RDT & DTI & TD & Al & RCTI \\
\hline $\begin{array}{l}\text { Body weight } \\
\text { (BW) }\end{array}$ & I & -0.22 & $0.13^{\mathrm{ns}}$ & $0.0 \mathrm{I}^{\mathrm{ns}}$ & -0.25 & 0.69 & $-0.14^{\text {ns }}$ & $0.02^{\text {ns }}$ & $-0.06^{\mathrm{ns}}$ & 0.38 & 0.64 & 0.26 \\
\hline $\begin{array}{l}\text { Cephalic index } \\
\text { (Cpl) }\end{array}$ & - & I & $-0.10^{\mathrm{ns}}$ & $-0.02^{\mathrm{ns}}$ & $0.0 \mathrm{I}^{\mathrm{ns}}$ & $-0.17^{\mathrm{ns}}$ & $0.10^{\mathrm{ns}}$ & $-0.03^{\mathrm{ns}}$ & 0.27 & $-0.12^{\mathrm{ns}}$ & $-0.12^{\text {ns }}$ & $0.12^{\mathrm{ns}}$ \\
\hline $\begin{array}{l}\text { Length index } \\
\text { (LI) }\end{array}$ & - & - & I & 0.57 & 0.59 & 0.47 & -0.98 & 0.59 & $-0.16^{\mathrm{ns}}$ & 0.68 & $0.05^{\text {ns }}$ & 0.43 \\
\hline $\begin{array}{l}\text { Depth index } \\
\text { (DI) }\end{array}$ & - & - & - & I & $0.10^{\text {ns }}$ & 0.4 & -0.55 & 0.99 & -0.28 & 0.61 & -0.24 & 0.26 \\
\hline Body index (BI) & - & - & - & - & I & -0.33 & -0.58 & $0.1 I^{\mathrm{ns}}$ & $0.06^{\mathrm{ns}}$ & -0.19 & 0.2 & $-0.09^{n s}$ \\
\hline $\begin{array}{l}\text { Conformation } \\
\text { index }(\mathrm{Cl})\end{array}$ & - & - & - & - & - & I & -0.48 & 0.41 & -0.25 & 0.88 & 0.3 & 0.51 \\
\hline $\begin{array}{l}\text { Proportionality } \\
\text { (Pr) }\end{array}$ & - & - & - & - & - & - & I & -0.56 & 0.21 & -0.67 & $-0.06^{\mathrm{ns}}$ & -0.4 \\
\hline $\begin{array}{l}\text { Relative depth } \\
\text { of thorax (RDT) }\end{array}$ & - & - & - & - & - & - & - & I & -0.28 & 0.61 & -0.23 & 0.26 \\
\hline $\begin{array}{l}\text { Dactyl thorax } \\
\text { index (DTI) } \\
\text { Thoracic }\end{array}$ & - & - & - & - & - & - & - & - & I & -0.27 & $0.0 \mathrm{I}^{\mathrm{ns}}$ & 0.61 \\
\hline $\begin{array}{l}\text { development } \\
\text { (TD) }\end{array}$ & - & - & - & - & - & - & - & - & - & I & $-0.12^{\mathrm{ns}}$ & 0.6 \\
\hline Area index $(\mathrm{Al})$ & - & - & - & - & - & - & - & - & - & - & I & $-0.09^{n s}$ \\
\hline $\begin{array}{l}\text { Relative cannon } \\
\text { thickness index } \\
(\mathrm{RCTI})\end{array}$ & - & - & - & - & - & - & - & - & - & - & - & I \\
\hline
\end{tabular}

$*(\mathrm{P}<0.05) ; \mathrm{ns}(\mathrm{P}>0.05)$

Citation: Putra WPB, Ilham F. Principal component analysis of body measurements and body indices and their correlation with body weight in Katjang does of Indonesia.J Dairy Vet Anim Res. 2019;8(3): I 24-I34. DOI: I0.15406/jdvar.2019.08.00254 
Table 5 Communalities value of different body measurements and body indices in Katjang does of Indonesia.

\begin{tabular}{lll}
\hline Parameter & Initial & Extraction \\
\hline Body measurements & & \\
Face length & I & 0.673 \\
Face width & I & 0.702 \\
Face height & I & 0.529 \\
Ear length & I & 0.729 \\
Ear width & I & 0.772 \\
Body length & I & 0.627 \\
Withers height & I & 0.437 \\
Chest width & I & 0.556 \\
Chest depth & I & 0.632 \\
Chest girth & I & 0.806 \\
Cannon bone circumference & I & 0.675 \\
Body indices & & \\
Cephalic index & I \\
Length index & I & 0.398 \\
Depth index & I & 0.968 \\
Body index & I & 0.866 \\
Conformation index & I & 0.996 \\
Proportionality & I & 0.966 \\
Relative depth of thorax & I & 0.944 \\
Dactyl thorax index & I & 0.869 \\
Thoracic development & I & 0.999 \\
Area index & I \\
Relative cannon thickness index & 0.723 \\
\hline & 0.969 \\
\hline
\end{tabular}

Table 6 Total variance explained by different components of body measurements and body indices in Katjang does of Indonesia.

\begin{tabular}{|c|c|c|c|c|c|c|c|c|c|}
\hline \multirow[b]{2}{*}{$\begin{array}{l}\text { Group/ } \\
\text { Component }\end{array}$} & \multicolumn{3}{|c|}{ Initial eigen values } & \multicolumn{3}{|c|}{$\begin{array}{l}\text { Extraction sums of squared } \\
\text { loadings }\end{array}$} & \multicolumn{3}{|c|}{$\begin{array}{l}\text { Rotation sums of squared } \\
\text { loadings }\end{array}$} \\
\hline & Total & $\begin{array}{l}\text { variance } \\
\text { (\%) }\end{array}$ & $\begin{array}{l}\text { Cumulative } \\
\text { (\%) }\end{array}$ & Total & $\begin{array}{l}\text { Variance } \\
(\%)\end{array}$ & $\begin{array}{l}\text { Cumulative } \\
\text { (\%) }\end{array}$ & Total & $\begin{array}{l}\text { Variance } \\
\text { (\%) }\end{array}$ & $\begin{array}{l}\text { Cumulative } \\
\text { (\%) }\end{array}$ \\
\hline
\end{tabular}

\begin{tabular}{|c|c|c|c|c|c|c|c|c|c|}
\hline \multicolumn{10}{|c|}{ Body measurements } \\
\hline I & 4.544 & 41.31 & 41.31 & 4.544 & 41.31 & 41.31 & 2.626 & 23.876 & 23.876 \\
\hline 2 & 1.508 & $13.7 \mid$ & 55.02 & 1.508 & |3.7| & 55.02 & 2.388 & 21.706 & 45.582 \\
\hline 3 & 1.086 & 9.873 & 64.893 & 1.086 & 9.873 & 64.893 & 2.124 & $|9.31|$ & 64.893 \\
\hline 4 & 0.771 & 7.005 & 71.898 & - & - & - & - & - & - \\
\hline 5 & 0.65 & 5.913 & 77.812 & - & - & - & - & - & - \\
\hline 6 & 0.616 & 5.596 & 83.407 & - & - & - & - & - & - \\
\hline 7 & 0.526 & 4.783 & 88.191 & - & - & - & - & - & - \\
\hline 8 & 0.464 & 4.22 & 92.411 & - & - & - & - & - & - \\
\hline 9 & 0.416 & 3.786 & 96.197 & - & - & - & - & - & - \\
\hline 10 & 0.246 & 2.24 & 98.437 & - & - & - & - & - & - \\
\hline II & 0.172 & 1.563 & 100 & - & - & - & - & - & - \\
\hline
\end{tabular}

Citation: Putra WPB, Ilham F. Principal component analysis of body measurements and body indices and their correlation with body weight in Katjang does of Indonesia.J Dairy Vet Anim Res. 2019;8(3):I24-I34. DOI: 10.15406/jdvar.2019.08.00254 
Table Continued

\begin{tabular}{|c|c|c|c|c|c|c|c|c|c|}
\hline \multirow[b]{2}{*}{$\begin{array}{l}\text { Group/ } \\
\text { Component }\end{array}$} & \multicolumn{3}{|c|}{ Initial eigen values } & \multicolumn{3}{|c|}{$\begin{array}{l}\text { Extraction sums of squared } \\
\text { loadings }\end{array}$} & \multicolumn{3}{|c|}{$\begin{array}{l}\text { Rotation sums of squared } \\
\text { loadings }\end{array}$} \\
\hline & Total & $\begin{array}{l}\text { variance } \\
(\%)\end{array}$ & $\begin{array}{l}\text { Cumulative } \\
\text { (\%) }\end{array}$ & Total & $\begin{array}{l}\text { Variance } \\
(\%)\end{array}$ & $\begin{array}{l}\text { Cumulative } \\
(\%)\end{array}$ & Total & $\begin{array}{l}\text { Variance } \\
(\%)\end{array}$ & $\begin{array}{l}\text { Cumulative } \\
\text { (\%) }\end{array}$ \\
\hline \multicolumn{10}{|l|}{ Body indices } \\
\hline I & 4.565 & 41.501 & 41.501 & 4.565 & 41.501 & 41.501 & 3.187 & 28.977 & 28.977 \\
\hline 2 & 1.799 & 16.355 & 57.856 & 1.799 & 16.355 & 57.856 & 2.651 & 24.104 & 53.081 \\
\hline 3 & 1.728 & 15.706 & 73.562 & 1.728 & 15.706 & 73.562 & 1.968 & 17.894 & 70.975 \\
\hline 4 & 1.46 & | 3.277 & 86.839 & 1.46 & 13.277 & 86.839 & 1.745 & 15.865 & 86.839 \\
\hline 5 & 0.816 & 7.416 & 94.255 & - & - & - & - & - & - \\
\hline 6 & 0.607 & 5.52 & 99.776 & - & - & - & - & - & - \\
\hline 7 & 0.017 & 0.151 & 99.926 & - & - & - & - & - & - \\
\hline 8 & 0.003 & 0.03 & 99.957 & - & - & - & - & - & - \\
\hline 9 & 0.002 & 0.019 & 99.976 & - & - & - & - & - & - \\
\hline 10 & 0.001 & 0.012 & 99.989 & - & - & - & - & - & - \\
\hline II & 0.001 & 0.011 & 100 & - & - & - & - & - & - \\
\hline
\end{tabular}

Table 7 Rotated component matrix of different factors for body measurements and body indices in Katjang does of Indonesia.

\begin{tabular}{|c|c|c|c|c|}
\hline \multirow[t]{2}{*}{ Parameter } & \multicolumn{4}{|c|}{ Principal component } \\
\hline & $\mathbf{I}$ & 2 & 3 & 4 \\
\hline \multicolumn{5}{|l|}{ Body measurements } \\
\hline Face length ${ }^{2}$ & 0.36 & 0.595 & 0.435 & - \\
\hline Face width ${ }^{3}$ & -0.102 & 0.163 & 0.815 & - \\
\hline Face height ${ }^{1}$ & 0.666 & 0.278 & 0.092 & - \\
\hline Ear length ${ }^{2}$ & 0.017 & 0.853 & 0.043 & - \\
\hline Ear width ${ }^{2}$ & 0.16 & 0.819 & 0.275 & - \\
\hline Body length' & 0.667 & 0.424 & 0.041 & - \\
\hline Withers height ${ }^{3}$ & 0.363 & 0.272 & 0.481 & - \\
\hline Chest width ${ }^{3}$ & 0.437 & -0.18 & 0.577 & - \\
\hline Chest depth' & 0.775 & -0.164 & 0.074 & - \\
\hline Chest girth' & 0.766 & 0.249 & 0.396 & - \\
\hline Cannon bone circumferance ${ }^{3}$ & 0.248 & 0.396 & 0.676 & - \\
\hline \multicolumn{5}{|l|}{ Body indices } \\
\hline Cephalic index ${ }^{4}$ & -0.0198 & -0.03 & 0.236 & 0.55 \\
\hline Length index ${ }^{2}$ & 0.471 & 0.845 & 0.175 & -0.028 \\
\hline Depth index ${ }^{3}$ & 0.408 & 0.364 & 0.737 & -0.157 \\
\hline Body index ${ }^{2}$ & -0.363 & 0.922 & -0.112 & 0.052 \\
\hline Conformation index' & 0.964 & 0.044 & -0.05 & -0.181 \\
\hline Proportionality ${ }^{3}$ & -0.466 & -0.835 & -0.161 & 0.063 \\
\hline Relative depth of thorax ${ }^{3}$ & 0.413 & 0.38 & 0.728 & -0.155 \\
\hline Dactyl thorax index ${ }^{4}$ & -0.056 & -0.045 & -0.239 & 0.915 \\
\hline Thoracic development ${ }^{\prime}$ & 0.899 & 0.194 & 0.317 & -0.085 \\
\hline Area index ${ }^{3}$ & 0.16 & 0.224 & -0.78 & -0.197 \\
\hline Relative cannon thickness index' & 0.69 & 0.141 & 0.049 & 0.686 \\
\hline
\end{tabular}

I,2,3,4 elements of the each component

Citation: Putra WPB, Ilham F. Principal component analysis of body measurements and body indices and their correlation with body weight in Katjang does of Indonesia.J Dairy Vet Anim Res. 2019;8(3): I 24-I34. DOI: I0.15406/jdvar.2019.08.00254 
Table 8 Linear regression model of body weight on original body measurements (PCI) and their component score.

\begin{tabular}{|c|c|c|c|}
\hline \multirow[t]{2}{*}{ Model } & Prediction equation & $\mathbf{R}^{2}$ & SE \\
\hline & Original body measurements as predictors & & \\
\hline I & $\mathrm{BW}=2.80(\mathrm{FH})-7.34$ & 0.35 & 4.01 \\
\hline 2 & $\mathrm{BW}=0.65(\mathrm{BL})-12.05$ & 0.32 & 4.1 \\
\hline 3 & $\mathrm{BW}=0.95(\mathrm{CD})-2.34$ & 0.15 & 4.58 \\
\hline 4 & $\mathrm{BW}=0.88(\mathrm{CG})-34.10$ & 0.69 & 2.76 \\
\hline \multirow[t]{2}{*}{5} & $\mathrm{BW}=0.72(\mathrm{FH})+0.1 \mathrm{I}(\mathrm{BL})+0.75(\mathrm{CG})-0.10(\mathrm{CD})-37.79$ & 0.71 & 2.71 \\
\hline & Principal components as predictors & & \\
\hline I & $B W=0.43 P C_{1}-43.74$ & 0.63 & 3.05 \\
\hline 2 & $B W=0.003 P C_{2}-4.00$ & 0.6 & 3.14 \\
\hline 3 & $\mathrm{BW}=0.65 \mathrm{PC}_{3}-0.52$ & 0.52 & 3.44 \\
\hline 4 & $\mathrm{BW}=0.32 \mathrm{PC}_{1}+0.001 \mathrm{PC}_{2}-29.94$ & 0.63 & 3.04 \\
\hline 5 & $B W=0.32 P_{1}+0.001 P_{2}+0.008 P C_{3}-30.17$ & 0.63 & 3.06 \\
\hline
\end{tabular}

BW, body weight; FH, face height; BL, body length; CD, chest depth; CG, chest girth; PC, principal component; R2, coefficient of determination; SE, standard error

Table 9 Linear regression model of body weight on original body indices (PCI) and their component score.

\begin{tabular}{|c|c|c|c|}
\hline Model & Prediction equation & $\mathrm{R}^{2}$ & SE \\
\hline & Original body indices as predictors & & \\
\hline I & $\mathrm{BW}=0.33(\mathrm{Cl})-\mathrm{I} .29$ & 0.47 & 3.6 \\
\hline 2 & $B W=21.77(T D)+0.16$ & 0.15 & 4.58 \\
\hline 3 & $B W=I .19(R C T I)+12.09$ & 0.07 & 4.79 \\
\hline \multirow[t]{2}{*}{4} & $B W=0.73(\mathrm{Cl})+0.38(\mathrm{RCTI})-57.26(\mathrm{TD})+30.16$ & 0.69 & 2.82 \\
\hline & Principal components as predictors & & \\
\hline I & $B W=0.06 P_{1}-3.90$ & 0.53 & 3.42 \\
\hline 2 & $B W=0.04 P_{2}-0.57$ & 0.39 & 3.88 \\
\hline 3 & $B W=-0.01 \quad P C_{3}-0.50$ & 0.4 & 3.83 \\
\hline 4 & $\mathrm{BW}=1.26-0.04 \mathrm{PC} 4$ & 0.42 & 3.79 \\
\hline 5 & $B W=0.22 P C_{1}-0.13 P C_{2}+1.43$ & 0.72 & 2.66 \\
\hline 6 & $B W=0.22 P C_{1}-0.13 P C_{2}-0.01 P_{3}+1.45$ & 0.72 & 2.67 \\
\hline 7 & $B W=0.22 P C_{1}-0.13 P C_{2}-0.01 P C_{3}+0.03 P C_{4}-0.10$ & 0.72 & 2.68 \\
\hline
\end{tabular}

BW, body weight; $\mathrm{FH}$, face height; BL, body length; CD, chest depth; CG, chest girth; PC, principal component; R2, coefficient of determination; SE, standard error 

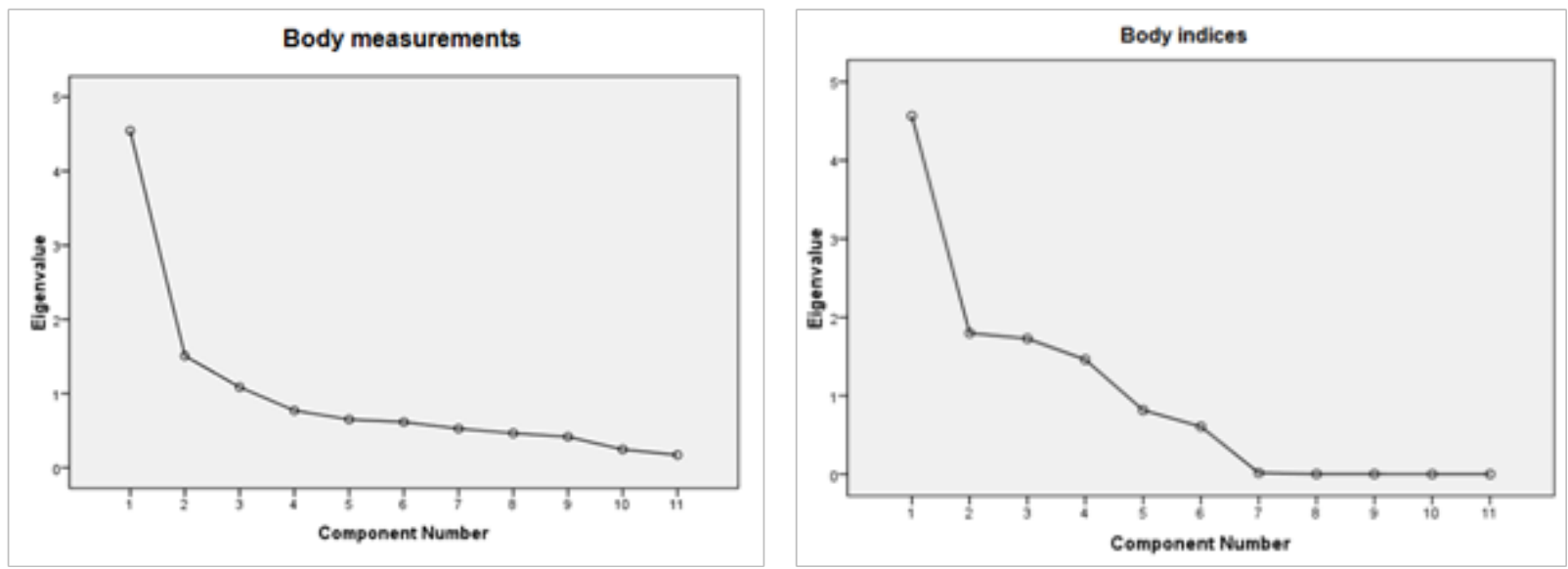

Figure 2 Scree plot showing component number with eigenvalues for body measurements and body indices in Katjang does of Indonesia.

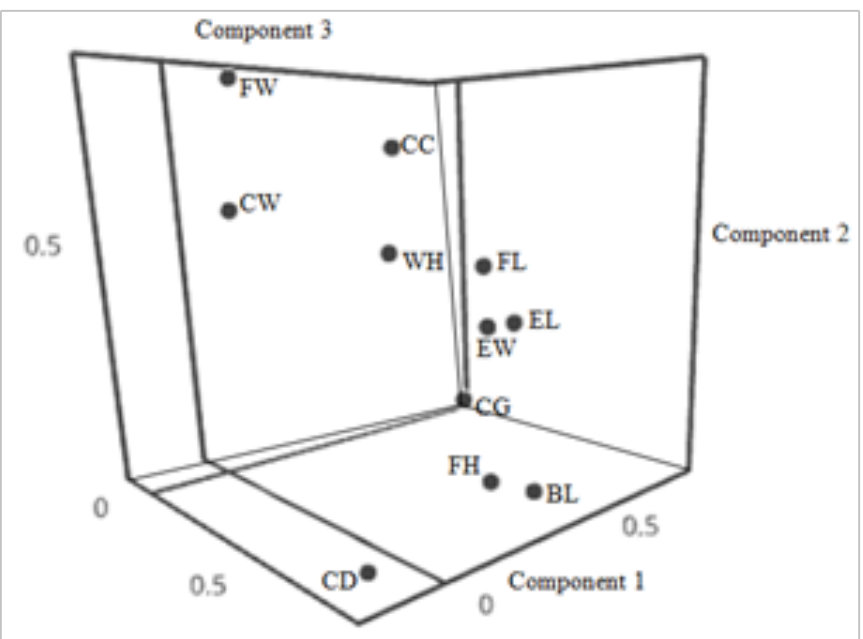

Figure 3 Component plot of body measurements in the Katjang does in rotate space consisted of face length (FL), face width (FW), face height (FH), ear length (EL), ear width (EW), body length $(B L)$, withers height $(\mathrm{WH})$, chest width $(\mathrm{CW})$, chest depth $(\mathrm{CD})$, chest girth $(\mathrm{CG})$ and cannon bone circumference (CC).

\section{Conclusion}

The principal component analysis (PCA) for body measurements and body indices in the present study can be used to predict body weight of Katjang does. The PC1 of body measurements can be used for body weight prediction in Katjang does with $\mathrm{R} 2=0.63$. Moreover, the PC1 and PC2 of body indices were more accurate for body weight prediction with $\mathrm{R} 2=0.72$. Further research with large number of sample is important to get the accurate formula for body weight prediction of Katjang goat in the future.

\section{Acknowledgments}

The authors would like to be grateful to all farmers of the Katjang goat in Bone Bolango Regency, who allowed the measurements and observation of their goat

\section{Conflicts of interest}

The author declares that there no conflicts of interest.

\section{References}

1. Muladno. Livestock and Animal Health Statistics. Jakarta, Indonesia: Directorate General of Livestock and Animal Health. Ministry of Agriculture of Indonesia. 2015.

2. Adiwinarti R, Kustantinah, Budisatria IGS. Improving the performance of local Kacang goats using ruminally undegradable protein feeds. Asian J Anim Sci. 2016;10:262-267.

3. Sodiq A, Soedito A, Ezzat ST. Reproduction rate of Kacang and Peranakan Etawah goats under village production systems in Indonesia. International Research for Food Security. 2003;1-7.

4. Simon DL, Buchenauer D. Genetic Diversity of European Livestock Breed. Wageningen, the Netherland: The Netherlands Hardback. 1993.

5. Mwacharo JM, Okeyo AM, Kamande GK. The small East African Shorthorn zebu cows in Kenya. Trop Anim Health Prod. 2006;38(1):65-74.

6. Yakubu A. Principal component analysis of the conformation traits of Yankasa sheep. Biotech Anim Husband. 2013;29(1):65-74.

7. Salako AE. Application of morphological indices in the assessment of type and function in sheep. Int J Morph. 2006;24(1):8-13.

8. Okpeku M, Abdulmojeed Y, Sunday OP. Application of multivariate principal component analysis to morphological characterization of indigenous goats in Southern Nigeria. Acta Agric Slovenica. 2011;98(2):101-109.

9. Eyduran E, Waheed A, Tariq MM. Prediction of live weight from morphological characteristics of commercial goat in Pakistan using factor and principal component scores in multiple regression. J Anim Plant Sci. 2013;23(6):1432-1540.

10. Khargharia G, Kadirvel G, Kumar S. Principal component analysis of morphological traits of Assam hill goat in Eastern Himalayan India. $J$ Anim Plant Sci. 2015;25(5):1251-1258.

11. Birteeb PT, Lomo R. Phenotypic characterization and weight estimation from linear body traits of West African Dwarf goats reared in the traditional zone of Ghana. Livest Res Rur Develop. 2015;27(9). 
12. Khan MA, Tariq MM, Eyduran E. Estimating body weight from several body measurements in Harnai sheep without multicollinearity problem. J Anim Plant Sci. 2014;24(1):120-126.

13. Udeh I. Prediction of body weight in rabbits using principal component factor scores in multiple linear regression model. Int $J$ Bioflux Soc. 2013;3(1):1-6.

14. Akinsola OM, Nwagu BI, Orunmuyi M. Prediction of body weight from body measurements in rabbits using principal component analysis. Ann Biol Sci. 2014;2(1):1-6.

15. Paul S, Mamy K, Moinuddin MA. Characterization of Black Bengal Goat. J Bangladesh Agril Univ. 2011;9(1):61-66.

16. Yakubu A, Adebowale ES, Ikhide GI. Comparative multivariate analysis of biometric traits of West African Dwarf and Red Sokoto goats. Trop Anim Health Prod. 2011;43(3):561-566.

17. Pares-Casanova PM. Body weight is an important trait for comparisons of goat breeds. Iranian J Appl Anim Sci. 2015;5(2):463-466.

18. Shoyombo AJ, Izebere J, Animashahun RA. Age and sex based multivariate analysis of body morphology using PCA. Sch J Agric Vet Sci. 2015;2(5):352-355.

19. Boujenane I. Derqaoui L, Nouamane G. Morphological differentiation between two Morrocan goat breeds. J Livest Sci Tech. 2016;4(2):31-38

20. Riva J, Rizzi R, Marelli S. Body measurements in Bergamasca sheep. Small Rum Res. 2004;55(1-3):221-227.

21. SalakoAE. Principal component factor analysis of the morphostructure of immature Uda sheep. Int J Morph. 2006;24:571-574.

22. Osaiyuwu $\mathrm{OH}$, Akinyemi MO, Salako AE. Factor analysis of the morphostructure of mature Balami sheep. Res J Anim Sci. 2010;4(2):63-65.

23. Legaz E, Cervantes I, Perez-Cabal MA. Multivariate characterisation of morphological traits in Assaf (Assaf.E) sheep. Small Rum Res. 2011;100(2-3):122-130.

24. Mavule BS, Muchenje V, Bezuidenhout CC. Morphological stucture of Zulu sheep based on principal component analysis of body measurements. Small Rum Res. 2013;111(1-3):23-30.

25. Birteeb PT, Sunday OP, Michael OO. Analysis of the body structure of Djallonke sheep using multideterminant approach. Anim Genet Res. 2014;54:65-72.

26. Yakubu A, Ogah DM, Idahor KO. Principal component analysis of the morphostructural indices of White Fulani cattle. Trakia J Sci. 2009; 7:67-73.

27. Pundir RK, Singh PK, Singh KP. Factor analysis of biometric traits of Kankrej cows to explain body conformation. Asian-Aust J Anim Sci. 2011;24(4):449-456.
28. Tolenkhomba TC, Konsam DS, Singh NS. Factor analysis of body measurements of local cows of Manipur, India. Int Multidisciplin Res J. 2012;2:77-82.

29. Ferreira TA, Idalmo GP, Aurora MGG. Morphological traits and type of dairy goats registered in Brazil from 1976 to 2009. R Braz Zootec. 2013;42:857-861.

30. Pares-Casanova PM, Sinfreu I, Villalba D. Application of varimax rotated principal component analysis in quantifying some zoometrical traits of relic cow. Korean J Vet Res. 2013;53(1):7-10.

31. Boujenane I. Multivariate characterisation of Oulmes-Zaer and Tidili cattle using the morphological traits. Iranian J Appl Anim Sci. 2015;5(2):293-299.

32. Vohra V, Niranjan SK, Mishra AK. Phenotypic characterization and multivariate analysis to explain body conformation in lesser known buffalo (Bubalus bubalis) from north India. Asian Australas J Anim Sci. 2015;28(3):311-317.

33. Staiger EA, Rebecca RB, Nathan BS. Morphological variation in Gaited horse breeds. J Equine Vet Sci. 2016;43:55-65.

34. Udeh I, Ogbu CC. Principal component analysis of three strains of Broiler chicken. Sci World J. 2011;6:11-14.

35. Chacon E, Fernando M, Francisco V. Morphological measurements and body indices for Cuban Creole goats and their crossbred. $R$ Braz Zootec. 2011;40:1671-1679.

36. Mamy K, Syaflee M, Rahman MSR. Morphometric characterization of Katjang goat of Malaysia. Bang Journal of Animal Sci. 2016;45(3):17-24.

37. Elmaz O, Mehmet C, Aykut AA. The determination of some morphological traits and phenotypic correlations of Turkish Hair goat (Kilkecisi) breed reared in extensive conditions in Turkey. Eurasian J Vet Sci. 2016;32:94-100.

38. Herrera M, Rodero E, Gutierrez MJ. Application of multifactorial discriminant analysis in the morphostructural differentiation of Andalusian caprine breeds. Small Rum Res. 1996;22(1):39-47.

39. Bingol M, Ozdal G, Turgut A. Some productive characteristics and body measurements of Norduz goats of Turkey. Trop Anim Health Prod. 2012;44(3):545-550.

40. Elmaz O, Mustofa S, Nuri M. The determination of some morphological characteristics of Honamli goat and kids, defined as a new indigenius goat breed of Turkey. Kafkas Univ Vet Fak Derg. 2012;18(3):481-485.

41. Syuhada I, Denie H, Andiana S. Identification of Wonosobo ewes body weight and measurements in a group of Wonosobo sheep farmers of Kejajar Sub-District Wonosobo Regency. JIT. 2015;4:1-13. 